\title{
Equalization, Regional Development, and Political Trust: The Section 36/Atlantic Accords Controversy
}

\section{James Bickerton*}

\section{Introduction}

The controversy generated by the federal government's unilateral alteration of the Atlantic Accords, ${ }^{1}$ and the subsequent bitter political standoff between the federal government and the provinces of Nova Scotia and Newfoundland and Labrador, was the initial stimulus for this article. The agreements, the alleged breach of trust involved in their unilateral alteration, and the political fallout, manoeuvrings, and negotiations that followed, raise a number of issues about the mechanisms and pathologies of executive federalism in Canada. This episode also provides some insight into a continuing source of misunderstanding and grievance that persists in centre-periphery relations in Canada - the issues of equalization and regional development. The purpose of this article is to use the controversy as a case study to inquire into these issues, with a view to making an incremental contribution to the critical literature on the institutions of Canadian federalism.

This study begins with an examination of the intergovernmental agreements known as the Atlantic Accords, but expands inevitably beyond this to inquire into the broader constitutional, fiscal, and political context for the accords. In particular, this article focuses on section 36 of the Constitution Act, 1982, which addresses equalization and regional development. ${ }^{2}$ The major commitment to regional equity in section 36 has proven to be both a powerful mechanism of integration in the Canadian federation and a continuing source of frustration, representing as it does a form of social contract at best imperfectly observed or fulfilled. After examining the problems associated with the implementation of section 36 and its connection to the controversy surrounding the Atlantic Accords, this article will conclude with some reflections on the factors affecting trust in intergovernmental relationships and offer some strategies for coping with these factors with a view to avoiding, limiting, or better managing politically destabilizing and regionally alienating controversies and conflicts within the federation.

It seems clear that a key variable in the Atlantic Accords controversy, as well as the longer term problems associated with the implementation of the commitments embodied in section 36 of the Constitution, is political trust. Trust is an important element in federations, and particularly in intergovernmental negotiations and agreements. As a political variable, trust can be seen to have both a moral and a strategic dimension. Daniel Elazar sees federal unions as based on moral covenants which bind the partners together in mutual respect and recognition. Samuel LaSelva has inquired into the moral foundations of Canadian federalism. In both cases, the morality of federalism - its ethos or ethic - relies heavily on trust ties between the federating partners. Whether the federating partners are peoples or distinct regional communities, the spirit of federalism - a union based and continually renewed upon the mutual consent and agreement of the partners - will be observed. ${ }^{3}$ 
Stephan Dupré, writing on the role of trust as it affects the workability of interstate or "executive" federalism, has stressed the importance of honouring the norms of intergovernmental relations rather than just the strict legalities. These norms are reinforced through the establishment and maintenance of trust ties among intergovernmental decision makers and officials, generated over time through the mutual recognition and honouring of negotiated agreements. Dupré also notes that these trust ties are most likely to be the product of ongoing functional relations among officials rather than "summit relations" among political executives, due to the fact that the former generally operate more smoothly and predictably. In particular, Dupré notes that the inherently quantifiable character of fiscal relations in Canada, the common vocabulary and network formation of finance officials, and the fixed maximum five-year term of fiscal arrangements ("nothing is forever"), make it an area where the mechanisms of executive federalism have perhaps the best chance of generating successful outcomes. While this may indeed be true of negotiated agreements that address problems and manage or moderate intergovernmental conflict, even here the workability of the model can be rendered inoperable by the intrusion of political factors. ${ }^{4}$

Trust is essential to building and utilizing a form of social capital in federations. It makes possible the more effective and efficient operation of intergovernmental consultative and decision-making processes, in short, the functional mechanisms of intergovernmentalism. As well, in a more generic sense, trust is a central factor in the realm of contracts as a basic prerequisite of good-faith negotiations and agreements between individuals or institutional actors. Contractual relations involve a continuum of measures and mechanisms that can be used to enable and enforce agreements, ranging from the negotiation of trust-based oral agreements to legally binding contracts with detailed requirements. ${ }^{5}$

An expected political consequence of broken trust ties, especially in the case of repeated occurrences, is the erosion of federal norms and assumptions that underlie a federal culture or ethic; a pronounced contraction in the reservoir of social capital that both relies upon and contributes to cooperation and trust; and lower levels of legitimacy, initially for political authorities, but eventually for the political regime or even the political community as a whole. Such consequences certainly will make future intergovernmental cooperation and negotiation less likely and more difficult. It will also make it more prone to negative outcomes, especially where nonjusticiable, open-ended, or flexible agreements are concerned. This is the case because negotiations in the context of low levels of trust, if they are to be successful, generally require agreements featuring verifiable commitments and therefore require the inclusion of strict enforcement mechanisms. ${ }^{6}$

In this connection, it has been recognized that institutional development can reduce the need for and the role of political trust. In effect, the fewer institutions there are, the more is trust needed. One reason for this is that routinization (a byproduct of institutionalization) makes it less likely that diversions from established understandings and practices will occur. Higher levels of institutionalization also generally involve the greater prevalence of, and accepted recourse to, decision rules, dispute resolution mechanisms, procedures for clarifying accountabilities, and other bureaucratic supports, all of which can make trust less central or essential to intergovernmental relations. On the other hand, as noted by Arthur Benz, one of the consequences of increased institutionalization in federations can be reduced flexibility and the accumulation of rigidities in intergovernmental relations, with the courts used more regularly to resolve conflicts and ultimately to act as the arbiter of intergovernmental relationships. ${ }^{\text {? }}$

\section{Section 36 of the Constitution Act, 1982}

Section 36 of the Constitution Act, 1982 entrenches a commitment on the part of Parliament and the Government of Canada to the principle of making equalization payments to ensure that provincial governments have sufficient revenues to provide reasonably compa- 
rable levels of public services to all Canadians at reasonably comparable levels of taxation (36-2). It also contains a commitment on the part of Parliament and the provincial legislatures, together with their governments, to further economic development to reduce regional disparities (36-1). These constitutional commitments can be understood to embody trust that the federal spending power will be used to advance regional equity.

Experts in fiscal federalism generally acknowledge that while equalization payments have dramatically reduced the discrepancies in fiscal capacity among provinces, the equalization commitment in section 36 has never truly been fulfilled, primarily because of the inadequacies of the formula used between 1982 and 2007 to determine payments. A formula based on fiscal capacity rather than actual costs or need, the construction of a national average based on a five-province standard which excluded Alberta and its resource revenues, and later the employment of a cap on equalization payments, all contributed to federal transfer payments to poorer provinces that were less generous than they needed to be if the federal government's section 36 commitments were to be fully realized. The inevitable result of this, not surprisingly, was somewhat lower levels of public services at somewhat higher levels of taxation, along with higher levels of public debt in recipient provinces, all of which indicates a greater fiscal effort for services of equal or lesser quality. ${ }^{8}$

As for reducing regional economic disparities, understood to be the underlying cause of differing provincial fiscal capacities, the federal commitment to this principle has been downplayed and progressively defunded since its constitutional entrenchment in 1982, with declining regional development spending arguably reflecting a fading federal commitment to advancing regional equity. ${ }^{9}$

However, it also should be noted here that it may not be just the federal government that has fallen somewhat short of its constitutional commitments under section 36. A recent lawsuit involving the Government of Nova Scotia and Cape Breton Regional Municipality (CBRM) raises both the question of whether the commitments in section 36 (with regard to both equalization and regional development) are legally binding on governments, and also whether provinces have an obligation to distribute equalization funds to municipalities based on a provincial variation of the same fundamental principle propounded in section 36 - in this case ensuring reasonably equivalent public services to all Nova Scotians at reasonably equivalent levels of taxation. The Nova Scotia Supreme Court has rendered an initial decision on the case, rejecting the CBRM's legal action on the basis that the question on which it seeks a judicial ruling is nonjusticiable. ${ }^{10}$ Regardless of the final outcome in this matter, the underlying political problem provoking the municipality to seek redress through the courts is basically one of trust, specifically the lack of trust or the perception of broken trust in terms of the intergovernmental relationship between the province of Nova Scotia and its second largest municipality. ${ }^{11}$

\section{The Atlantic Accords}

The 2005 Atlantic Accords were bilateral agreements negotiated between Prime Minister Paul Martin, Premier Danny Williams of Newfoundland and Labrador (NL), and Premier John Hamm of Nova Scotia (NS). The negotiations were conducted in the context of an announced "new framework" for equalization that would have resulted in reduced and capped payments, and ongoing provincial discontent over the 70-80 percent federal clawback of provincial offshore resource revenues. Both of these federal initiatives were perceived by the affected provinces as breaches of trust, the first related to the section 36 equalization commitment, and the second to a federal government undertaking in the original 1985-6 Atlantic Accords that the two provinces would be the principal beneficiaries of the development of offshore oil and gas resources. ${ }^{12}$ This was recognized at the time as an important step in advancing the goals of regional development and equity.

The political context for bilateral agreements in 2005 was a politically weakened federal government in a precarious minority situa- 
tion, which revalued the political leverage of the periphery and enabled small provinces to wring concessions from Ottawa that no doubt would not otherwise have been forthcoming. Certainly finance department officials, the guardians of the federal treasury and managers of federalprovincial fiscal arrangements, were unhappy with the deal. The new Atlantic Accords gave the provinces in question 100 percent of their offshore revenues without any corresponding reduction in (or cap on) their equalization entitlements; indeed, the deal included an automatic 3.5 percent increase in equalization payments until 2009-10. This effectively delinked equalization payments to NL and NS from the national formula. If these provinces did not reach the average equalization fiscal capacity standard by 2012 , the agreement would be extended for another eight years; should they reach the standard during that period and therefore no longer qualify for equalization, then they would get transitional payments for two years. Furthermore, the two provinces were granted upfront advance payment against their future revenue streams. This last concession reflects these provinces' immediate fiscal need, the limitations of their trust in the federal commitment, and the softening of the federal government's bargaining position during the course of the negotiations, primarily due to Martin's personal intervention. This, of course, spawned the inevitable opposition and resentments from political and bureaucratic actors outside the region, who saw the deal as containing a generous "no strings attached" grant component at odds with the basic rationale of the equalization program. ${ }^{13}$

It is worth noting here that both the federal commitments in section 36 , and the federal undertaking in the Atlantic Accords, can be understood to involve questions of trust rather than legality because they ultimately rested on the use of the federal spending power, which placed the federal government in a strong if not unassailable legal position as confirmed by the Supreme Court of Canada in its 1991 decision Reference re Canada Assistance Plan (B.C.):

the Supreme Court made it clear that the doctrine of parliamentary sovereignty trumps intergovernmental agreements, and that any "legitimate expectations" on the part of the provinces that such agreements could not be altered unilaterally had no legal effect. ${ }^{14}$

In effect, the federal Parliament (and therefore government) has the discretionary power to spend or not to spend, and it can neither be required to nor prevented from doing so by an intergovernmental agreement to that effect. ${ }^{15}$

\section{Overturning the Accords}

Soon after the defeat of the Martin Liberal government by the Harper-led Conservatives in 2006, the recommendations of a number of ongoing government-commissioned and private sector studies on equalization and fiscal federalism were released. Most important of these was the federal government's own O'Brien Report, ${ }^{16}$ which recommended changes to the equalization formula that would broaden and enrich the program's fiscal base. This recommendation would simultaneously act on the concern that the equalization program should be placed on a principled national basis, and also address provincial complaints about a vertical fiscal imbalance that was fattening federal budgetary surpluses, while straining provincial finances. The O'Brien Report proposed a ten-province standard in place of the five-province formula in place since 1982, while including 50 percent of all natural resource revenues in the formula for calculating entitlements. A further recommendation was that equalization payments to any receiving province be capped to ensure that the fiscal capacity of a recipient province did not exceed that of the lowest nonreceiving province (Ontario), regardless of its entitlement under the new formula. ${ }^{17}$

In its March 2007 budget, ${ }^{18}$ the Harper government adopted the main recommendations of the O'Brien Report, which effectively killed the federal commitment in the Atlantic Accords to delink the offshore oil and gas revenues of Newfoundland and Labrador and Nova Scotia from their equalization entitlements. This decision was heavily criticized by the two provincial governments as a direct and specific breach of trust, and both embarked on political campaigns to have the accords reinstated in their original form and intent. In the course of this campaign, 
the provincial governments, both Conservative, called on Conservative MPs in Ottawa to join them in demanding the reinstatement of the accords. One Nova Scotia MP, Bill Casey, did so, and was promptly expelled from the Conservative caucus. The popularity of his stance put intense political pressure on the two remaining Nova Scotia Conservative MPs, one of whom was Minister of Foreign Affairs Peter MacKay. Eventually, the federal government and Nova Scotia negotiated a new alternative deal, which both sides claimed repairs the fiscal damage done to the province by the equalization provisions in the 2007 federal budget. ${ }^{19}$ However, this new deal was greeted with widespread scepticism from the Nova Scotia public and political commentators. ${ }^{20}$ Typical was the observation of the banished Conservative MP Casey, who, continuing to call for the restoration of the original accord, claimed the issue was primarily one of broken trust rather than dollars and cents. Meanwhile, no negotiations took place with an embittered, truculent, and highly popular NL premier, who consistently refused to consider anything less than the reinstatement of the 2005 Atlantic Accord. ${ }^{21}$

\section{Explaining the Trust Involved and the Politics of its Breach}

What exactly was the basis for the trust broken by this chain of events and developments in fiscal federalism? The most proximate and glaring was the decision to adopt new equalization measures that would effectively overturn the accords. What two provinces assumed were hard-won victories sealed into intergovernmental agreements that would be respected by any subsequent federal government, very quickly proved to be illusory. This sent political shock waves through the affected provinces, and quickly eroded trust and confidence in the honesty and fairness of the federal government in its dealings with the region. Behind the ensuing public and governmental outrage, however, was a longer-term regional grievance over the distribution of the benefits of offshore development. In the set of original Atlantic Accords from the 1980s, ${ }^{22} \mathrm{NS}$ and NL had been promised that they would be the principal beneficiaries of offshore oil and gas, and yet the federal government had persisted in imposing a clawback of 70-80 percent of offshore revenue through the equalization program; furthermore, Ottawa remained the main beneficiary of the profits from offshore oil because of its direct share in offshore oil developments, as well as revenue derived from various federal taxes. For instance, as of 2007 Ottawa has received four times more revenue from Hibernia than the province of Newfoundland and Labrador ( $\$ 4.8$ versus $\$ 1.2$ billion). ${ }^{23}$ As well, the 1986 offshore agreement with Nova Scotia contained a promise to financially compensate the province for giving up its claim to ownership of the offshore (referred to as the "Crown share"), a promise that had never been fulfilled. ${ }^{24}$ It was this long-simmering dispute that motivated Nova Scotia Premier John Hamm's "Campaign for Fairness," which he patiently yet persistently flogged at political and business gatherings across the country during Paul Martin's prime ministership. ${ }^{25}$

To fully understand the anger and resentment in the reaction of Nova Scotians and Newfoundlanders to this particular episode of federal deal breaking, one must go beyond the immediate broken trust argument (essentially, "a deal is a deal"), and even beyond the longerterm broken trust related to changes in the federal commitment in the original 1985-6 Atlantic Accords that these provinces would be the "principal beneficiaries" of offshore oil and gas development. Beyond this, it is worth noting that the accords were negotiated in the context of, and partially in response to, the longstanding partial or nonfulfillment of the commitments set out in section 36 of the Constitution Act, 1982.

It cannot be forgotten that in 1982 the federal government committed itself to furthering economic development to reduce regional disparities, and to an equalization program that would provide all provinces with the fiscal capacity to provide their residents with reasonably comparable levels of public services at reasonably comparable levels of taxation. If it is to be understood just why the generous provisions of the 2005 Atlantic Accords were not viewed as excessive or unfair by the governments and 
publics of the two Atlantic provinces involved (in contrast to much of the reaction elsewhere in Canada), at least part of the explanation lies in the continuing perception within these provinces that the section 36 constitutional commitments have never been properly upheld or acted upon, and that federal efforts with regard to regional development in the region have been sorely lacking. This lingering dissatisfaction with past federal performance has been fused with a widespread sense that the economic returns to the provinces - promised by the rising value of nonrenewable offshore resources - was perhaps their last, best chance to break out of their perpetual "have not" status. If the resource were to be depleted without any discernible gain in economic advantage because of the federal government's policy of clawing back equalization payments, then this would not only be a blatant injustice and inequity, but also a historic opportunity forgone. In this sense, the accords were seen as belated federal acknowledgement of the need to somehow compensate the region for longstanding federal shortcomings in fulfilling its section 36 equalization commitments, and its outright failure in the area of regional development.

The Harper government decided to adopt a new equalization formula that would effectively negate the Atlantic Accords, despite this strong regional sentiment that the benefits conferred by the accords were both justifiable and overdue. This decision can be explained by a number of proximate and strategic political and bureaucratic factors. Since Harper had promised to maintain the accords prior to his elevation to prime minister in the federal election of 2006 (as loudly proclaimed by Premier Williams), reneging on this commitment constituted, in effect, a double breach of trust (personal and governmental). Presumably, this was not a decision to be taken lightly or without some foreknowledge of the likely political consequences in the affected provinces. In fact, there were a number of good reasons for the federal government to act as it did, if viewed from the point of view of strategic political calculation or party ideology. To begin, there was the hostility of the federal Department of Finance to Martin's deal on equalization, and the clear recommenda- tion of the O'Brien Report to cap equalization payments at the level of the lowest nonrecipient province. Also important was the Government of Ontario's vehement criticism of the Atlantic Accords and its opposition to any enrichment of the equalization formula. ${ }^{26}$ Likely the most important consideration, however, was the political need to craft a response acceptable to Québec and Ontario on the issue of the fiscal imbalance, the resolution of which was another promise of the Harper Conservatives. This imperative was accomplished mostly with the adoption of the O'Brien formula on equalization, which benefited Québec more than any other recipient province, and with the adoption of strictly equal per capita social transfers (excluding the health transfer, which for the time being will continue to be determined by its own separate accord). As Doug Brown remarks: "This essentially ended a long-term bias in favour of fiscally-challenged provinces - what Ontario and others somewhat misleadingly termed equalization outside the equalization program." 27

Essentially, the Atlantic Accords were sacrificed to accomplish these broader political objectives, a decision made easier by the political isolation of Newfoundland and Labrador and Nova Scotia. Whereas in the past the Atlantic provinces could count on Québec's influence and coincident interest in equalization to augment and reinforce their own weak political situation, in this instance it was in Québec's interest to support implementation of the O'Brien Report. Finally, and in a more ideological vein, the Harper Conservatives' Reform-Canadian Alliance lineage instils in the government an aversion to differentiated treatment for provinces in the context of its embrace of equality as the same treatment for all (ergo, one national formula), its long-standing priority of advancing the goal of provincial autonomy over the redistribution required by regional equity, and in this connection its neoliberal hostility toward regional-development spending of the sort traditionally associated with section 36 commitments. ${ }^{28}$

These observations on the factors explaining the federal about-face on the Atlantic Accords raise yet again the question of how interparty 
coalition politics comes into play in the conduct and institutional makeup of intergovernmental relations. In the absence of brokerage parties operating within an integrated national party system, and with the Canadian aversion to interparty legislative coalitions, "the party governments of Canada have of necessity played a game of intergovernmental coalition politics, but it is a game that does not appear to be as effective for managing the federation as either brokerage parties or coalition governments." 29

As argued by Ken Carty and Steven Wolinetz, the competitive dynamics of Canadian party politics often work to aggravate rather than ameliorate regional tensions, though this may begin as an attempt to manage federalprovincial issues through bargaining and accommodation. This is generally played out in a number of

under-institutionalized forums which are poorly integrated and seek to obfuscate the partisan face of the interests involved ... Coalition activity emerges around issues, not programs ... ongoing policy making is not governed by consistent partisan orientations or coherent electoral mandates ... The party coalitions are constantly changing ... [with] no guarantee that those who begin a decision-making cycle will be around to see it through. ${ }^{30}$

This is an apt description of the competitive partisan dynamics, interparty coalitions, and accommodative intergovernmental bargaining of the Martin-Harper period, as they pertain to the section 36/Atlantic Accords controversy. And not surprisingly, building alliances and creating obligations in the world of federal-provincial accommodation can lead to a competitive outbidding that is corrosive of national politics. This concern is made all the more pressing by the fact that federal-party governments are by necessity engaged in a "big tent" process of interest aggregation, while provincial-party governments benefit from the articulation of provincial interests. The two partners in the coalition are therefore frequently working at crosspurposes. In short, the "fleeting, shifting, and oversized" coalitions that governing parties build across the federal-provincial divide to manage the federation tend to be "unresponsive, fragile and electorally unaccountable ... Locked into this syndrome, Canadian parties hardly seem the instruments that a democratic citizenry can use for managing its federation." 31

\section{Remedies and "Coping Strategies"}

This review of the section 36/Atlantic Accords controversy - a case study of broken trust ties in intergovernmental relations - identifies the complexity of the intertwined issues at play, simultaneously rooted in the exigencies, biases, and pathologies of executive federalism, regionalism, regional development, and the national party system. Of course, the inevitable question arises: what can or should be done? There are a range of possible remedies that might be applied, or strategies devised, for coping with the factors that contribute to eroding trust ties in this area of intergovernmental relations. Consideration of remedies and strategies is worthwhile because limiting negative outcomes, or making future instances of trust breaches less likely, might avoid the political damage such instances inflict on the capacity of the intergovernmental relations system to effectively manage the federation. As a subset of proposed reforms that address the systemic deficiencies of executive federalism, these remedies and strategies can be seen to fall into the three general categories first identified by Richard Simeon in the late 1970s: disentanglement of the two orders of government, reforming federal institutions to better represent provincial concerns and interests within those institutions, and changes to improve the machinery of intergovernmental relations. ${ }^{32}$

Some of the measures discussed below pertain directly and specifically to the political situation of the federation's smaller provinces, as illuminated by the section 36/Atlantic Accords controversy. Other proposed "remedies" are, in fact, reforms which address more broadly the shortcomings of executive federalism as practiced in Canada, and the "federalism deficit" that hampers and distorts the regional representativeness, responsiveness, and accountability of the political regime. 


\section{1) Disentanglement}

"In some ways," Richard Simeon and Amy Nugent have argued, "the remedy for the dysfunctions of intergovernmentalism is to have less of it." ${ }^{33}$ It can be argued that the disentanglement of federal and provincial governments in Canada has been occurring over the past two decades and is now fairly well advanced, thus reducing the need for intergovernmental coordination. Certainly in the area of fiscal relations, provincial budgets are now far more reliant on own-source revenues than they once were, with federal transfers declining in significance and the federal government far more judicious in using its spending power to leverage provincial government expenditures. ${ }^{34}$ One idea to further disentangle federal and provincial orders of government - in the process reducing the need for intergovernmental transfers or agreements - is to follow the reasoning of Québec's Seguin Report, ${ }^{35}$ and agree to an exchange or redivision of tax jurisdiction and revenues that would simplify the system and provide the provinces with sufficient revenue for their program needs, without recourse to federal transfers (for example, give the federal goods and services tax [GST] to the provinces, in exchange for provincial corporate taxes and the phasing out of the Canada Social Transfer). This would further remove the federal government (and its spending power) from provincial jurisdiction. ${ }^{36}$

While disentanglement may be an appealing device for reducing intergovernmental conflict, it is often difficult in the extreme to achieve in practice. Certainly this would appear to be the case for the equalization-offshore resources conflict. Federal and provincial levels of government are incapable of disengagement, yet they are resistant to any solution to their conflict that would require their further entanglement. Thus, one solution to the equalization-offshore conundrum is for offshore revenues to be sequestered by the legal owner of the resource (the Government of Canada) and placed in a special federal regional development fund. Doing so would remove this revenue stream from provincial equalization calculations, while keeping it available for regional de- velopment purposes (broadly defined). However, this "solution" would also reinstate a major regional development role in Atlantic Canada for the federal government. While this may or may not be a prospect relished by federal governments (either now or in the future), it can be surmised that there would be stiff resistance from the affected provinces, not least because of their own bitter experience with federal governments failing to fulfill their section $36 \mathrm{com}$ mitments ("once burnt, twice shy"). This makes the prospect of an expanded federal role in provincial economic development - using what otherwise would have been provincial resource revenues - unsavoury in the extreme, and in the end completely unacceptable as a way out of the equalization-offshore problem.

For other observers, the whole idea of disentanglement at a time of growing global interdependence is considered an unwise strategy for Canadian intergovernmental harmony. Virtually all important problems cut across jurisdictional lines, creating interdependence and necessitating intergovernmental machinery "to assist in multilevel governance or achieve coordination on matters of common concern." ${ }^{37}$ Certainly, with regard to fiscal relations a number of public finance economists oppose the cession of further tax room to the provinces as a remedy to intergovernmental conflict. Robin Boadway, for example, bases his opposition to ceding further tax room to the provinces on tax-harmonization considerations, and the importance of federal transfers as a means of accomplishing national objectives of economic efficiency and equity. In effect, federal dominance in revenue raising leads not only to a more harmonized tax system, with advantages for the efficiency of the national economy, but also

\footnotetext{
allows for the use of the spending power as an instrument for inducing national standards in provincial programs in accord with the principles set out in Section 36 of the Constitution Act. Given the division of legislative responsibilities, the use of the spending power is arguably the only effective policy instrument available for the federal government to fulfill these commitments [emphasis added]. ${ }^{38}$
} 


\section{2) Reforming federal institutions}

This solution would involve institutional reforms aimed at improving the regional representativeness, responsiveness, and accountability of the federal Parliament and government. In particular, proposed reforms to the Senate and the electoral system in the House of Commons could go some way toward accomplishing these ends. A reformed Senate might be a more legitimate chamber for representing and protecting the interests of the smaller provinces, and electoral reform might create a more stable partisan environment and produce multiparty coalition governments, which generally result in more consensual and incremental, less precipitate decision making and policy change. While comprehensive Senate reform or other previously proposed constitutional changes (such as the section 36 changes included in the 1992 Charlottetown Accord $^{39}$ ) seem unlikely to happen anytime soon (if ever), and momentum for electoral system change seems once again to have stalled, such fundamental reform remains the best long-term strategy for addressing the democratic and federal deficits of the current Canadian political system.

Despite the formidable political obstacles to institutional reform that goes beyond mere tinkering (such as minor changes in the role of parliamentary committees), there are still possibilities for constructive institutional evolution that fall short of constitutional amendment. One example is the Harper government's attempt to use simple legislation and changes to the executive's power of appointment to progressively install elected senators with limited terms of office. If successful, this initiative might well result, over time, in a politically legitimate and regionally responsive Senate that could be invaluable for representing and protecting the interests of smaller provinces in the federation. Another possibility is an expanded role for the Supreme Court of Canada in intergovernmental relations. As noted by Johanne Poirier, if the Court were to begin to make intergovernmental agreements "legally more robust" by giving greater weight in their rulings to the federal principle involved in such agreements, the contractual concept of legitimate expectations, and the idea that constitutional conventions have emerged around such agreements, the Court might begin to place limits on parliamentary sovereignty in recognition of claims flowing from intergovernmental agreements. ${ }^{40}$

\section{3) Improving intergovernmental relations machinery}

As noted by Ron Watts, "as long as Canada continues to combine parliamentary and federal institutions, it will be difficult to eliminate 'executive federalism' and therefore, the focus should be on harnessing 'executive federalism' in order to make it more workable." ${ }^{\text {"1 }}$ However, the current situation appears to range from poor to abysmal. In its 2006 Report on Fiscal Imbalance, the Council of the Federation described intergovernmental relations as "corrosive." ${ }^{\prime 2}$ The provincial governments interviewed for the report

\section{identified an across-the-board decline in trust which they attributed to irregular federal- provincial meetings, called on an ad-hoc ba- sis; last minute negotiations on major issues; wedge strategies used by the federal govern- ment to divide and rule; intergovernmental agreements ... ignored at will ... There is little permanence, predictability or consistency when intergovernmental agreements, many of which are achieved only with great difficulty, can be cancelled or altered unilaterally. ${ }^{43}$}

Moreover, it seems likely that this pattern of interaction is being worsened by the progressive shift from departmentalized to institutionalized cabinets, and now to prime ministerial government (what Donald Savoie calls "Court government") in which cabinet has joined Parliament as an institution being bypassed by the prime minister's office. This "doubtless [has] exacerbated intergovernmental tension and served to weaken Cabinet as a mirror of Canada's regional diversity." ${ }^{\prime 4}$

One change that could improve the situation is for governments in Canada to agree to use legally binding contracts, backed up by legislation, in place of loose intergovernmental agreements. This would give the parties greater assurance that an agreement will be judicially enforced and not unilaterally altered or termi- 
nated. However, this proposal would be difficult to execute in many cases due to the complexity of the policy field involved; a necessary degree of indeterminacy and flexibility in intergovernmental agreements might also be lost. It is often the case that regional development agreements are very complex arrangements, though there are instances where legally binding contracts work well. One example is the gas tax transfer agreements that funnel federal tax revenue through the provinces to municipalities. These agreements take the form of highly formalized, legally binding contracts. Another impediment to this "remedy" is provincial resistance to the level of federal oversight and accountability that the federal government incorporates into many intergovernmental agreements. The more these federal mechanisms appear in intergovernmental agreements, the less likely are provinces to agree to them. ${ }^{45}$

There are also some modest proposals that have been put forward from time to time to improve the performance of Canada's intergovernmental machinery. First, an often repeated recommendation has been to regularize and properly institutionalize first minister's conferences (FMCs), such that they would no longer be hostage to the political needs of the incumbent prime minister. They should be held annually and at fixed times. As noted by Martin Papillon and Richard Simeon, "a more highly structured FMC might help build trust and cooperation and transform the culture of confrontation." ${ }^{46}$ A corollary of this change would be to develop a formal process for concluding, ratifying, and modifying intergovernmental agreements. Finally, creating legislative standing committees on intergovernmental relations at both federal and provincial levels might improve scrutiny and transparency by giving both legislators and citizens a greater role in the process. Legislatures might also be asked to ratify major intergovernmental agreements like the Social Union Framework Agreement or the Atlantic Accords. ${ }^{47}$

As Dupré argued a quarter-century ago, what is most lacking in Canada's system of intergovernmental relations is mutual trust. Over time, "the extent of distrust seems to have in- creased as relations moved from line officials, to central agency officials, to ministers, and then to first ministers. Institutional reform cannot create trust if the basic sense of common purpose and federal 'comity' is missing." ${ }^{8} 8$ The section 36/Atlantic Accords controversy is only the latest confirmation of this; it represents yet another illustration of what is a worsening systemic problem for Canadian federalism.

\section{Notes}

* James Bickerton, Department of Political Science, St. Francis Xavier University.

1 Canada, Arrangement between the Government of Canada and the Government of Newfoundland and Labrador on Offshore Revenues (14 February 2005), online: Government of Newfoundland and Labrador <http://www.gov.nf.ca/atlanticaccord/agreement.htm $>$; Canada, Arrangement between the Government of Canada and the Government of Nova Scotia on Offshore Revenues (14 February 2005), online: Department of Finance Canada $<$ http://www.fin.gc.ca/FEDPROV/PDF/ nsae.pdf $>$.

2 Constitution Act, 1982, being Schedule B to the Canada Act 1982 (U.K.), 1982, c.11. Section 36 reads as follows: "36 (1) Without altering the legislative authority of Parliament or the provincial legislatures, or the rights of any of them with respect to the exercise of their legislative authority, Parliament and the legislatures, together with the government of Canada and the provincial governments are committed to a) promoting equal opportunities for the well-being of $\mathrm{Ca}$ nadians; furthering economic development to reduce disparities in opportunities; c) providing essential public services of reasonable quality to all Canadians. 36 (2) Parliament and the Government of Canada are committed to the principle of making equalization payments to ensure that provincial governments have sufficient revenues to provide reasonably comparable levels of public services at reasonably comparable levels of taxation."

3 Daniel Elazar, Exploring Federalism (Tuscaloosa: University of Alabama Press, 1987); Samuel LaSelva, The Moral Foundations of Canadian Federalism: Paradoxes, Achievements and Tragedies of Nationhood (Montreal: McGill-Queens University Press, 1996).

4 J. Stephan Dupré, "The Workability of Executive Federalism in Canada" in Herman Bakvis \& 
William M. Chandler, eds., Federalism and the Role of the State (Toronto: University of Toronto Press, 1987) 236. Dupré cites as an example the last Trudeau government's decision to pursue its counter-offensive against provincialism into the fiscal domain.

5 Organization for Economic Co-operation and Development (OECD), Linking Regions and Central Governments: Contracts for Regional Development (Paris: OECD Publishing, 2007).

6 Ibid. at 9-20.

7 Arthur Benz, "Trust and Mistrust in Intergovernmental Relations - The Case of Germany" (a presentation to the 8th CREQC Symposium entitled La dynamique confiance/méfiance dans les Etats fédéraux ou en voie de federalisation at the Université du Québec à Montréal, 23 November 2007) [unpublished].

8 Robin Boadway, "Should the Canadian Federation be Rebalanced? A Memo for Paul Martin" (Prepared for University of Windsor Faculty of Science Seminar Series, 18 November 2003) [unpublished], online: $<$ http://www.econ.queensu. ca/pub/faculty/boadway/windsor.pdf >; Harvey Lazar, "Opening Statement before the Senate Standing Committee on National Finances" in Proceedings of Standing Senate Committee on National Finance, No. 5 (31 March 2004).

9 Donald Savoie, Regional Economic Development: Canada's Search for Solutions, 2d ed. (Toronto: University of Toronto Press, 1992); Donald Savoie, Visiting Grandchildren: Economic Development in the Maritimes (Toronto: University of Toronto Press, 2006). Of course, there are a number of factors that contribute to an explanation for this federal failure to fulfill its regional development commitment: the embrace of the neoliberal paradigm by the federal government, the imposition of stern fiscal discipline on federal spending in the 1990s, the general political weakness of the Atlantic region and the inability of its federal representatives to protect regional interests, and the steadily diminishing political legitimacy for regional development spending after 1982.

10 Cape Breton (Regional Municipality) v. Nova Scotia (Attorney General), 2008 NSSC 111 (CanLII). As of June 2008, the municipality is mulling over the pros and cons of launching an appeal.

11 Laura Fraser, "C.B. lawsuit on hold for 60 days" The Chronicle Herald (24 May 2008) B1.

12 Canada, Memorandum of Agreement Between the Government of Canada and the Government of Newfoundland and Labrador on Offshore Oil and Gas Resource Management and Revenue Sharing
(11 February 1985), online: Canada-Newfoundland and Labrador Offshore Petroleum Board $<$ http://www.cnlopb.nl.ca/pdfs/guidelines/aa mou.pdf $>$; Canada, Canada-Nova Scotia Offshore Petroleum Resources Accord (26 August 1986), online: Government of Nova Scotia <http://www. gov.ns.ca/energy/resources/RA/offshore/1986Canada-NS-Offshore-Petroleum-Resource-Accord.pdf $>$.

13 Jennifer Smith, "Canada: a noisy squabble over offshore oil and equalization" (2005) 4:3 Federations 19. Famous among the bargaining tactics used by Premier Danny Williams to jolt stalled negotiations was the calculated use of rhetorical and symbolic flourishes, through his populist stoking of Newfoundland and Labrador neonationalist sentiment and the dramatic gesture of lowering Canadian flags outside government buildings in the capital, St. John's.

14 Richard Simeon \& Amy Nugent, "Parliamentary Canada and Intergovernmental Canada: Exploring the Tensions" in Herman Bakvis \& Grace Skogstad, eds., Canadian Federalism: Performance, Effectiveness and Legitimacy, 2d ed. (Don Mills, Ontario: Oxford University Press, 2008) at 96; Reference Re Canada Assistance Plan (B.C.), 1991 SCC 74 (CanLII).

15 This probably explains PM Harper's initial "so sue me" reaction in Parliament to charges from Nova Scotia and Newfoundland that he blatantly had breached the Atlantic Accords.

16 Canada, Expert Panel on Equalization and Territorial Formula Financing, Achieving a National Purpose: Putting Equalization Back on Track, (Ottawa: Department of Finance, 2006) online: EQTFF-PFFT <http://www.eqtff-pfft.ca/epreports/EQ_Report_e.pdf > [O'Brien Report].

17 Al O'Brien, “Strengthening Canada's Territories and Putting Equalization Back on Track: The Report of the Expert Panel on Equalization and Territorial Formula Financing" (Paper presented at the Fiscal Federalism and the Future of Canada Conference delivered at the Institute of Intergovernmental Relations, 28 September 2006), online: Institute of Intergovernmental Relations $<$ http://www.queensu.ca/iigr/working/ fiscalImb/Obrien.pdf $>$. A further change to fiscal arrangements announced in the 2007 budget was a switch from variable cash transfers to the provinces under the CST and CHT, with some poorer provinces receiving an additional compensatory component in the transfer, to a system of unalloyed per capita payments, a change demanded by Ontario and highly beneficial to the larger, wealthier provinces. 
18 Canada, Department of Finance, Budget 2007: Aspire to a Stronger, Safer, Better Canada (Ottawa: Department of Finance, 2007), online: Department of Finance <http://www.budget. gc.ca/2007/index_e.html $>$.

19 Though the specifics of this new deal with Nova Scotia are complicated, the key elements are the federal promise of a back-end "insurance payment" in 2020 that will guarantee Nova Scotia suffers no financial penalty as the result of the 2007 budget changes. Stephen Maher, "Accord deal's value shrinking?" The Chronicle Herald (6 May 2008) A1.

20 Roger Taylor, "Nova Scotia accepts Wimpy deal, hopes for something later" The Chronicle Herald (12 October 2007) C1.

21 Campbell Clark, "Williams fumes at PM's deal with Nova Scotia" The Globe and Mail (11 October 2007) A8; "PM - no return to caucus for Casey" The Chronicle Herald (11 October 2007).

22 Supra note 12.

23 "The Hibernia Offshore Oil Project" The Sunday Herald, Nova Scotian supplement (18 November 2007) 4.

24 Supra note 12. As part of the Harper government's negotiated settlement with Nova Scotia in the wake of the Atlantic Accord controversy, a panel was established to adjudicate the dispute over the "Crown share" issue arising from federal nonfulfillment of the original Atlantic Accord. An agreement on the Crown share was reached in July, 2008, resulting in an award of \$870 million to the province, to be paid out over 15 years. Davene Jeffrey, "\$870m for Crown share" The Chronicle-Herald (14 July, 2008) 1.

25 "Campaign for Fairness" launched by Premier John F. Hamm (January 2001), online: Government of Nova Scotia <http://www.gov. ns.ca/fairness/>.

26 In fact, the rise of Ontario regionalism which has asserted itself in federal-provincial relations since the 1990s, can itself be traced to unilateral federal cuts to social transfers to the provinces in that decade, beginning with the "cap on CAP" in 1991, which discriminated against the better off provinces and in a recessionary period added to Ontario's rapidly expanding fiscal deficit at that time. Thenceforth, a more "Ontario first" stance has been adopted by the provincial government in the Canadian federation, particularly with regard to fiscal relations.

27 Douglas Brown, "Integration, Equity and Section 36” (2007) 37 Supreme Court Law Review (2d) 24.

Ibid. at 30 .
29 J. Peter Meekison, Hamish Telford \& Harvey Lazar, "The Institutions of Executive Federalism: Myths and Realities" in J. Peter Meekison, Telford \& Harvey Lazar, eds., Canada: The State of the Federation 2002: Reconsidering the Institutions of Executive Federalism (Montreal and Kingston: McGill-Queen's University Press, 2004) 3 at 12.

30 R. Kenneth Carty \& Steven B. Wolinetz, "Political Parties and the Canadian Federation's Coalition Politics" in J. Peter Meekison, Telford \& Harvey Lazar, ibid. at 67.

31 Ibid. at 74.

32 Supra note 29 at 7.

33 Supra note 14 at 105.

34 Peter Leslie, Ronald H. Neumann \& Russ Robinson, "Managing Canadian Fiscal Federalism" in J. Peter Meekison, Hamish Telford \& Harvey Lazar, supra note 29, 213 at 246.

35 Commission of Fiscal Imbalance, A New Division of Canada's Financial Resources (Québec: Bibliothèque nationale du Québec, 2002) [Seguin Report], online: Commission on Fiscal Imbalance $<$ http://www.councilofthefederation.ca/pdfs/Report_Fiscalim_Mar3106.pdf $>$.

36 Garth Stevenson, "Fiscal Federalism and the Burden of History" (Paper presented at the Fiscal Federalism and the Future of Canada Conference at the Institute of Intergovernmental Relations, Queen's University, Kingston, 28 September 2006) at 15, online: Institute of Intergovernmental Relations < http://www.queensu.ca/iigr/working/fiscalImb/Stevenson.pdf $>$.

37 Supra note 14 at 94.

38 Supra note 8 at 8-9.

39 Canada, Charlottetown Accord: Draft Legal Text (Ottawa: Queen's Printer, 1992).

40 Supra note 29 at 15 . See also Johanne Poirier, "Intergovernmental Agreements in Canada: At the Crossroads Between Law and Politics" in J. Peter Meekison, Telford \& Harvey Lazar, supra note 29, 225.

41 As sited in J. Peter Meekison, Telford \& Harvey Lazar, supra note 29 at 7.

42 Council of the Federation, Advisory Panel on Fiscal Imbalance, Reconciling the Irreconcilable: Addressing Canada's Fiscal Imbalance (Ottawa: Council of the Federation Secretariat, 2006) at 17, online: <http://www.councilofthefederation. ca/pdfs/Report_Fiscalim_Mar3106.pdf> [Report on Fiscal Imbalance].

43 Supra note 14 at 99-100 [quotation marks removed].

44 Supra note 29 at 13. See also Donald Savoie, Court Government and the Collapse of Account- 
ability in Canada and the United Kingdom (Toronto: University of Toronto Press, 2008).

45 Supra note 5 at 188-191.

46 Martin Papillon \& Richard Simeon, "The Weakest Link? First Ministers' Conferences in Canadian Intergovernmental Relations" in J. Peter

Meekison, Telford \& Harvey Lazar, supra note 29,113 at 132 .

$47 \quad$ Supra note 14 at 106.

48 Supra note 46 at 134. 